\title{
ANALYZING GREEN PURCHASING BEHAVIOR OF TURKISH AND PERSIAN CONSUMERS ${ }^{1}$
}

Sara MOSAVICHECHAKLOU²

Zehra BOZBAY ${ }^{3}$
Received Date (Başvuru Tarihi): 05/01/2020

Accepted Date (Kabul Tarihi): 23/03/2020

Published Date (Yayın Tarihi): 25/04/2020

\section{ABSTRACT}

Keywords:

Green Purchasing

Behavior,

Antecedents of Green Purchasing Behavior, Turkish Consumers, Persian Consumers

JEL Codes: M3, M31
Consumers being conscious about environmental issues tend to have favorable attitude to green purchasing. Offering eco-friendly products and services should be a good strategy for all companies wishing to provide competitive advantage in the marketplace. In the literature, a number of factors accepted as the antecedents of green purchasing behavior and this study examined eight factors of them. It is predicted that the factors which have an effect on the green purchasing behavior are different between the consumers having different nationality due to cultural differences. The purpose of this study is to determine the differences between both the antecedents of green purchasing behavior and green purchasing behavior of Turkish and Persian consumers. According to the results, differences are found between some antecedents of green purchasing behavior as environmental knowledge, social influence, environmental concern, perceived seriousness of environmental problems, concern for self-image, and green purchasing behavior of Turkish and Persian consumers.

\section{TÜRK VE İRANLI TÜKETICCILERIN YEŞİL SATIN ALMA DAVRANIŞLARININ}

\section{ANALIZi}

$\ddot{O} Z$

Anahtar Kelimeler:

Yeşil Satın Alma

Davranışı, Yeşil

Satın Alma

Davranışınıı

Öncülleri, Türk

Tüketiciler, Iranll

Tüketiciler

JEL Kodları:

M3, M31
Çevre sorunları hakkında bilinçli olan tüketiciler, yeşil satın almaya yönelik olumlu bir tutum sergileme eğilimindedirler. Çevre dostu ürün ve hizmet sunmak, pazarda rekabet avantajı sağlamak isteyen tüm işletmeler için iyi bir stratejidir. Literatürde yeşil satın alma davranışının öncülü olarak kabul edilen birçok faktör olup bu çalışmada sekiz öncül incelemiştir. Yeşil satın alma davranışı üzerinde etkisi olan faktörlerin kültürel farklılıklar nedeniyle farkl milliyetlere sahip tüketiciler arasında farkl olduğu tahmin edilmektedir. Bu çalışmanın amacl, Türk ve Iranlı tüketicilerin yeşil satın alma davranışlarının öncülleri ve yeşil satın alma davranışları arasındaki farklılıklarının belirlenmesidir. Elde edilen sonuçlara göre, Türk ve Iranlı tüketicilerin yeşil satın alma davranışının ve çevre bilgisi, sosyal etki, çevresel kaygl, çevresel sorunların algılanan ciddiyeti, kişisel imaj kaygısı ve yeşil satın alma davranışı gibi yeşil satın alma davranışı öncülleri arasında farklılıklar bulunmuştur.

\footnotetext{
${ }^{1}$ This study is derived from Sara Mosavichechaklou's master thesis called "A Comparative Study towards the Green Purchasing Behavior of Turkish and Persian Consumers".

${ }^{2}$ Istanbul University, Social Science Institute, Master of Marketing, srmsv1225@ gmail.com, ht.ps://orcid.org/0000-0002-5107-1015

${ }^{3}$ Corresponding Author; Assoc. Prof., Istanbul University, School of Business, Department of Marketing, zehrat@istanbul.edu.tr https://orcid.org/0000-0002-2728-8003
}

\section{Turkish Journal of Marketing Vol.:5 Issue:1 Year: 2020 pp. 37-58}

Bu makale, araştırma ve yayın etiğine uygun hazırlanmış ve ithenticate intihal taramasından geçirilmiştir. 


\section{INTRODUCTION}

Environmental issues are one of the most critical concepts for sustainability of human being in the world. The negative effects of the environmental problems are increasing in the world and the consumers tend to buy green products in order to prevent environmental damage. Green markets are carrying opportunities for gaining competitive advantage. Thus, it is very important for companies to understand consumers' preferences and green purchasing behavior.

Green marketing is planned marketing activities that cover the process starting from the design of environmentally friendly products to the after-use service of the products (Çetinkaya et al., 2017). Green consumers are defined as consumers who are sensitive about environmental issues (Soonthonsmai, 2007).

Nowadays, consumers are demanding more information about the social and ecological effects of the products that they are purchasing, and prefer environmentally friendly products (Renner, 2002). The number of green consumers is increasing day by day and the importance of understanding the reasons of green purchasing behavior and analyzing the antecedents that are effective on the green purchasing behavior are gaining importance. Understanding the factors effecting green purchasing behavior can help companies to produce products which will satisfy the green consumers.

In the literature, various factors affecting green purchasing behavior are examined. In this study, environmental knowledge, social influence, environmental attitudes, environmental concern, perceived seriousness of environmental problems, perceived environmental responsibility, perceived consumer effectiveness and concern for self-image are analyzed as antecedents of the green purchasing behavior and for understanding the green purchasing behavior of consumers in emerging markets, the differences between antecedents of the green purchasing behavior and green purchasing behavior of Turkish and Persian consumers are examined.

\section{THEORETICAL FRAMEWORK}

\subsection{Green Purchasing Behavior}

In parallel with the increase in environmental problems, consumers realized that they can have direct effect on environmental problems and it makes them to be careful in order to protect the environment (Zinkhan and Carlson, 1995). Consumers who are conscious about 
protecting the environmental issues started to buy eco-friendly products that do not pollute the environment and support environmental projects (Y1lmaz and Arslan, 2011: 2).

The numbers of studies in the literature on this field are increased as consumers prefer to buy environmentally friendly products. For example, Straughan and Roberts (1999) found that green buying behavior is affected by demographic characteristics of 235 university students in the United States. Follows and Jobber (2000) stated that consumers may buy green products if they believe their consumption will have a significant impact on the environment. Kim (2011) studied the role of collectivism, personal values and environmental attitudes on green purchasing behavior. Hartmann and Apaolaza-Ibanez (2012) argued that positive attitude towards eco-friendly products contribute to the purchase of green products. Hüseyin and Cankul (2010) conducted a study on the green buying behavior of Turkish university students. According to the results of this study, although most of the students are worried about destroying the environment, buying and using environmental products does not reflect these concerns. In a study conducted by Sharma (2014), it is determined that there are positive relationships between social influence, environmental habits and environmental protection behavior of consumers. Onurlubaş (2019) found that social influence and environmental awareness of the consumers have an effect on green product purchasing behavior.

\subsection{Antecedents of Green Purchasing Behavior}

Previous researchers found that various antecedent variables explain green purchasing behavior (Tilikidou, 2007; Lee, 2008; Lee, 2009; Akehurst et al., 2012; Uddin \& Khan, 2016). The success of companies in green marketing depends on analyzing the factors affecting the green purchasing behavior of consumers (Ünlüönen and Tayfun, 2003). According to Lee (2008), social influence is the most important factor which influences green purchasing behavior. In the study of Mostafa (2009), it is determined that environmental knowledge has a significant effect on consumers' green purchasing behavior. If a consumer has awareness about environment, he/she will probably prefer buying green products (Mostafa, 2009). According to Panni (2006), consumers who are more environmentally conscious buy more green products. Afsordegan et al. (2011) found the factors that have impact on the young Persian consumers' purchasing of green products are as social influence, environmental concerns, perceived environmental responsibility and concern for self-image in environmental protection. Another study in East Azerbaijan of Iran conducted by Bagheri (2014) demonstrated the effect of green marketing activities on green behavior. In the study, it 
is also found that some demographic features of consumers have moderating impact on the relationships between green marketing and green behavior.

Antecedents of green purchasing behavior effect on green purchasing behavior are often studied in the literature. Green purchasing behavior is examined by demographic variables, psychological factors, environmental and social values (Gilg et al., 2005: 482). To analyze consumers' green purchasing behavior, psychographic variables are found more important than demographic variables (Oliver, Volschenk and Smit, 2011). Mostafa (2009) claims that environmental attitude, concern, knowledge, altruism and skepticism are the major psychological factors that influence the green purchasing behavior of consumers. Studies like Lee (2008), Chan and Lau (2000) and D'Souza et al. (2006) searched the factors affecting green purchasing behavior. Lee (2008) used seven antecedent factors as environmental attitudes, environmental concern, perceived seriousness of environmental problems, perceived environmental responsibility, perceived effectiveness of environmental behavior and concern for self-image in environmental protection in his study of green purchasing behavior on young consumers in Hong Kong.

In this study, environmental knowledge, social influence, environmental attitudes, environmental concern, perceived seriousness of environmental problems, perceived environmental responsibility, perceived consumer effectiveness and concern for self-image are examined as psychological factors that influence green purchasing behavior.

\subsubsection{Environmental Knowledge}

Environmental knowledge is related to the solutions of environmental problems (Erten, 2004). There are different views about the relationship between environmental knowledge and purchase behavior. In the literature, some studies of environmental knowledge informed that it has low effect on behavior (Geller, 1981; Maloney and Ward, 1973; Muller and Taylor, 1991) while others report that a consumer's environmental behavior depends on his/her environmental knowledge, affect and intention (Chan and Yam, 1995). Consumers can make green purchasing when they have enough information about environmental issues (Prakash, 2002). Lai (2000) found that citizens in Hong Kong have environmental knowledge and therefore they are conscious about environmental issues. In a study conducted by Zainudin et al. (2013), it is found that environmental knowledge is an important indicator of consumers' green buying behavior and their green consumption. 


\subsubsection{Social Influence}

In general, consumption is strongly influenced by relational and inspiring reference groups (Hoyer and MacInnis, 2004). In a study conducted by Sharma (2014), it is determined that there is a positive relationship between social influence and environmental habits of consumers. Lascu and Zinkhan (1999) showed that the choice of a teenager usually coincides with the opinions of group of peers in the buying process. Khare et al. (2013) concluded that social influence and group prestige have a meaningful effect on the green purchasing behavior of 501 Indian consumers in six different cities of India. The study of Onurlubaş (2019) acknowledged that social influence has a moderately significant impact on green buying behavior.

\subsubsection{Environmental Attitude}

Environmental attitude is a concept that is related to the behavior that individuals choose against a situation (Gezer et al., 2006). In a study on Egyptian consumers, it is determined that the consumer's attitude towards green purchasing can directly affect the actual green buying behavior (Mostafa, 2007). According to Kim and Fortner (2006), one of the most important factors on environmental issues is environmental attitude. Özbay (2010) stated that activities have positive effects on students' academic success and environmental attitude.

\subsubsection{Environmental Concern}

Environmental concern refers to an attitude towards environmental issues (Schultz \& Zelezny, 1999). Tanrikulu (2015) found that environmental anxiety is one of the factors affecting the green purchasing behavior of consumers over 20 years of age. In the literature, it is found that consumers having environmental concern exhibit more sensitive behavior to the environment (Roberts, 1996; Lee 2008; Mostafa, 2007). The study of Kement (2018) showed that environmental concern and perceived ethical commitment have a positive impact on intention to go to green hotels. Also, it is found that an environmental concern of hotel consumers positively affects the perceived ethical mandatory.

\subsubsection{Perceived Seriousness of Environmental Problems}

Another important antecedent of green purchasing behavior is called perceived seriousness of environmental problems. In today's world where the effects of globalization are felt strongly in all sectors, environmental problems are the most important problems 
facing humanity (Özdemir, 2003). According to Ghimire and Mohai (2005), individuals are more affected by perceived seriousness of environmental problems than the real severity of those problems. Asian consumers consider environmental problems as bigger than consumers in Western countries (Lee, 2009).

\subsubsection{Perceived Environmental Responsibility}

Environmental responsibility is defined as a person's way of living (Fraj and Martinez, 2006). Environmentally responsible consumers are those who are ready to be responsible for a better sustainable future. Straughan and Roberts (1999) defined consumers that have environmental responsibility as typical, young, middle-income, educated and urban women. On the contrary, Samdahl and Robertson (1989) found no relationship between environmental responsibility and gender.

\subsubsection{Perceived Consumer Effectiveness}

Kinnear et al. (1974) defined perceived consumer effectiveness as measuring the individual's belief in the results of their actions (Majlath, 2010). Perceived consumer effectiveness is defined as the individual being aware of the steps he/she should take and not to make an environmental difference and position himself/herself at the center of the problems (Roberts, 1996). Many different researchers carried out studies on the subject from the past to the present and suggested that perceived consumer effectiveness is the determinant of environmental concern (Straughan and Roberts, 1999; Yahya et al., 2013; Lee et al., 2017). The study conducted by Saritas (2018) found that increase in green purchasing behavior positively affects perceived consumer effectiveness.

\subsubsection{Concern for Self-Image}

Concern for self-image can be explained as the attitudes and behaviors of consumers who are interested in their personal image about environmental problems. Concern for selfimage is found as the antecedent of green purchasing intention which affects green buying and green purchasing behavior of adolescents (Cheah, 2009; Lee, 2008). Baker and Ozaki (2008) determined that green purchasing behavior is affected by the environmental selfimage. 


\section{METHODOLOGY}

Researchers and human beings do have more attention to environment, environmental issues and especially to the environmental problems in today's world. The negative outcomes of environmental problems are perceived more severe than the recent years. For minimizing these severe effects and defeating the environmental problems, all green consumers are making efforts. For protecting the environment and minimizing the harmful effects of pollution, consumers realized that their green purchasing have ability to contribute environment positively thus consumers tend to buy green products. As a result of the changes in consumers' buying behavior, companies have to adopt the green products and services offered to consumers. Companies start to produce environment friendly products and apply green marketing strategies. As a conclusion of these efforts, the concept of "green marketing" occurs.

The purpose of this study is to determine the differences between the antecedents of green purchasing behavior and green purchasing behavior of Turkish and Persian consumers. A descriptive model is used in this research. According to this descriptive model as shown in Figure 1, it is aimed to specify the differences in antecedents and green purchasing behavior of Turkish and Persian consumers.

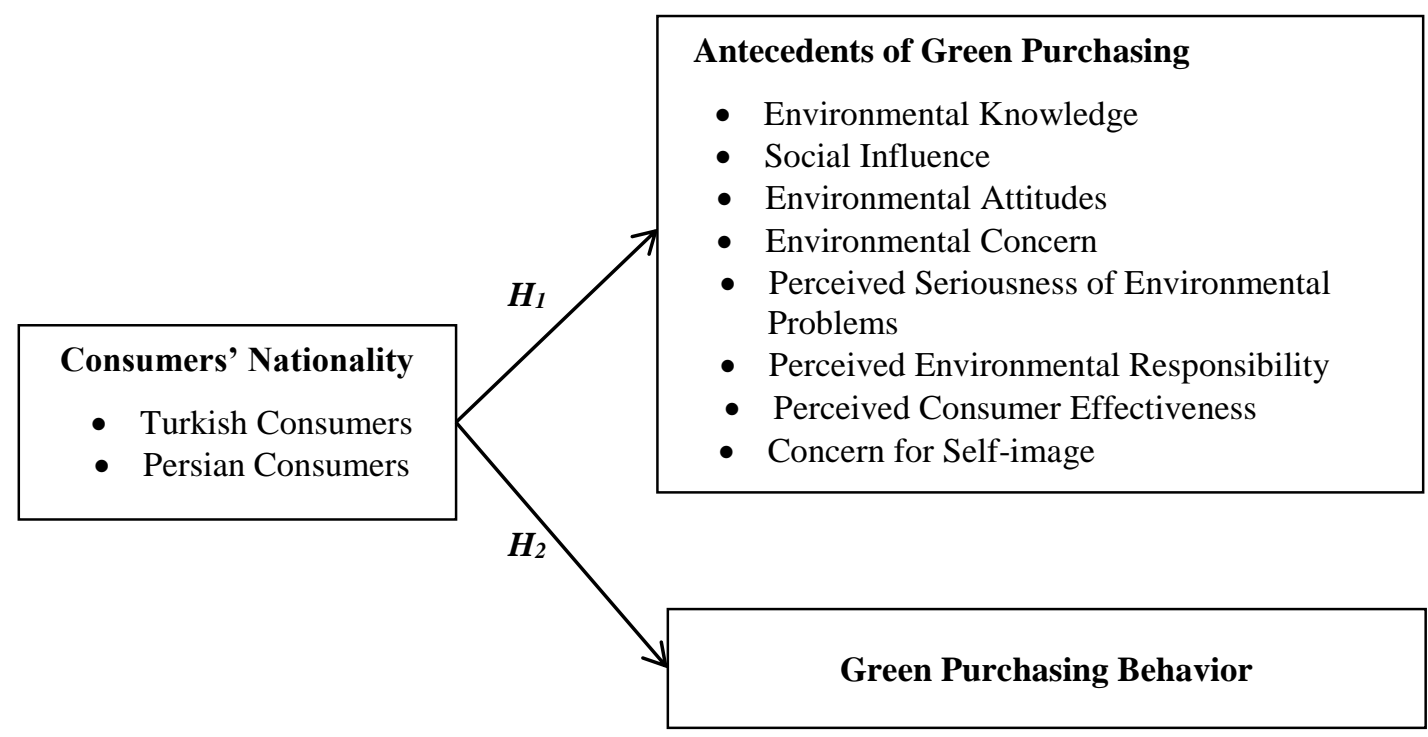

Figure 1. Research Model 
According to the model, hypotheses are developed as follows:

Hypothesis 1: There is a significant difference between the antecedents of green purchasing behavior of Turkish and Persian consumers.

Hypothesis 1a: There is a significant difference between environmental knowledge of Turkish and Persian consumers.

Hypothesis 1b: There is a significant difference between social influence of Turkish and Persian consumers.

Hypothesis 1c: There is a significant difference between environmental attitudes of Turkish and Persian consumers.

Hypothesis 1d: There is a significant difference between environmental concern of Turkish and Persian consumers.

Hypothesis 1e: There is a significant difference between perceived seriousness of environmental problems of Turkish and Persian consumers.

Hypothesis 1f: There is a significant difference between perceived environmental responsibility of Turkish and Persian consumers.

Hypothesis 1g: There is a significant difference between perceived consumer effectiveness of Turkish and Persian consumers.

Hypothesis 1h: There is a significant difference between concern for self-image of Turkish and Persian consumers.

Hypothesis 2: There is a significant difference between green purchasing behavior of Turkish and Persian consumers.

\subsection{Scope of the Study}

Turkey, having 82 million people living in, is a rapidly developing country. According to the IMF's world economic outlook database, Turkish economy is the $19^{\text {th }}$ largest economy in the world (Silver, 2019). Turkey has also a geopolitical importance because of its strategic location between Asia and Europe. On the other hand, Iran, having rich oil and natural reserves, has also geopolitical importance in the Middle East. In addition, Turkey and Iran are two neighboring countries with a common cultural heritage, known as the Turkish-Persian tradition, which was a prominent characteristic of the Ghaznavid, Seljuk, Ottoman dynasties, Timurid, Kara Koyunlu, Ak Koyunlu and Safavid empires (Hazır, 2015; Wikipedia, 2020). 
Due to geographical proximity, linguistic and ethnic relations, (e.g. Azerbaijanis are the second largest ethnicity in Iran who speak a Turkic language) Turkey and Iran affected each other culturally and economically throughout their history. At the same time Iran is the shortest route for Turkey in order to open to Central Asian markets. Moreover Turkey has an important role for Iran as it is the opening gate to the Balkans and European market. That's why Turkey is an important neighbor for Iran and on the contrary (Gurcemal, 2016; 17). Because of all these reasons, Turkish and Persian consumers are selected as the population of the study.

In the study, convenience sampling is used and the data is collected from 199 Turkish and 185 Persian consumers totally 384 consumers in January 2015. The research conducted via questionnaire in different districts of Istanbul and Tabriz and it is assumed that each of these districts reflects the different demographic characteristics.

Environmental knowledge scale is adopted from Lee (2011), Mohd Suki (2013), Mostafa (2006 and 2007); social influence scale is adopted from Lee (2008 and 2011), Mei et al. (2012), Sinnappan and Rahman (2011); environmental attitudes scale is adopted from Kaiser et al. (1999), Kotchen and Reiling (2000), Lee (2008), Mostafa (2007); environmental concern scale is adopted from Lee (2008), Mostafa (2007), Straughan and Roberts (1999); perceived seriousness of environmental problems is adopted from Garcia-Mira et al. (2005), Lee (2008), Moser and Uzzel (2003); perceived environmental responsibility scale is adopted from Lai (2000), Lee (2008), Manzo and Weinstein (1987); perceived consumer effectiveness scale is adopted from Lee (2008), Kim and Choi (2005), Straughan and Roberts (1999); concern for self-image scale is adopted from Cheah (2009), and Lee (2008); Green purchasing behavior is adopted from Fraj and Martine (2006), Leonidou et al. (2010), Lee (2008 and 2011) and Kim (2011). In the study, five point Likert scale which ranged from 1 (never disagree) to 5 (strongly agree) is used.

\subsection{Demographic Characteristics of the Sample}

In the study, 51.8\% (199) of the participants are Turkish and the $48.2 \%$ (185) of the participants are Persian. The demographic characteristics of the sample are shown in Table 1. 
Table 1. Demographic Characteristics of the Sample

\begin{tabular}{|c|c|c|c|c|c|c|}
\hline & \multicolumn{2}{|c|}{ Turkish Consumers } & \multicolumn{2}{|c|}{ Persian Consumers } & \multicolumn{2}{|c|}{ Total } \\
\hline & $\mathrm{F}$ & $\%$ & $\mathrm{~F}$ & $\%$ & $\mathrm{~F}$ & $\%$ \\
\hline \multicolumn{7}{|l|}{ Gender } \\
\hline Female & 122 & 61,30 & 72 & 38,90 & 194 & 50,50 \\
\hline Male & 77 & 38,70 & 113 & 61,10 & 190 & 49,50 \\
\hline Total & 199 & 100,0 & 185 & 100,0 & 384 & 100,0 \\
\hline \multicolumn{7}{|l|}{ Age } \\
\hline $18-25$ & 55 & 27,60 & 28 & 15,10 & 83 & 21,60 \\
\hline $26-33$ & 41 & 20,60 & 54 & 29,20 & 95 & 24,70 \\
\hline $34-41$ & 51 & 25,60 & 51 & 27,60 & 102 & 26,60 \\
\hline $42-49$ & 31 & 15,60 & 42 & 22,70 & 73 & 19,00 \\
\hline $50-57$ & 20 & 10,10 & 9 & 4,90 & 29 & 7,60 \\
\hline Over 58 & 1 & 0,50 & 1 & 0,50 & 2 & 0,50 \\
\hline Total & 199 & 100,0 & 185 & 100,0 & 384 & 100,0 \\
\hline \multicolumn{7}{|l|}{ Marital Status } \\
\hline Single & 99 & 49,70 & 61 & 33,00 & 160 & 41,70 \\
\hline Married & 100 & 50,30 & 124 & 67,00 & 224 & 58,30 \\
\hline Total & 199 & 100,0 & 185 & 100,0 & 384 & 100,0 \\
\hline \multicolumn{7}{|l|}{ Income } \\
\hline Under $500 \mathrm{TL}$ & 28 & 14,07 & 29 & 15,70 & 57 & 14,84 \\
\hline $501-1000 \mathrm{TL}$ & 30 & 15,08 & 30 & 16,20 & 60 & 15,63 \\
\hline $1001-1500 \mathrm{TL}$ & 32 & 16,08 & 43 & 23,20 & 75 & 19,53 \\
\hline $1501-2000 \mathrm{TL}$ & 14 & 7,03 & 37 & 20,00 & 51 & 13,28 \\
\hline $2001-2500 \mathrm{TL}$ & 20 & 10,05 & 31 & 16,80 & 51 & 13,28 \\
\hline $2501-3000 \mathrm{TL}$ & 20 & 10,05 & 12 & 6,50 & 32 & 8,33 \\
\hline Over $3001 \mathrm{TL}$ & 55 & 27,64 & 3 & 1,60 & 58 & 15,11 \\
\hline Total & 199 & 100,00 & 185 & 100,0 & 384 & 100,00 \\
\hline \multicolumn{7}{|l|}{ Education } \\
\hline Primary & 15 & 7,54 & 1 & 0,54 & 16 & 4,20 \\
\hline Secondary & 11 & 5,53 & 3 & 1,62 & 14 & 3,60 \\
\hline High school & 31 & 15,58 & 27 & 14,6 & 58 & 15,10 \\
\hline Associate & 13 & 6,53 & 35 & 18,92 & 48 & 12,50 \\
\hline Bachelor's & 90 & 45,22 & 83 & 44,87 & 173 & 45,10 \\
\hline Post Graduate & 28 & 14,07 & 28 & 15,13 & 56 & 14,60 \\
\hline Doctorate & 11 & 5,53 & 8 & 4,32 & 19 & 4,90 \\
\hline Total & 199 & 100,00 & 185 & 100,00 & 384 & 100,0 \\
\hline \multicolumn{7}{|l|}{$\begin{array}{l}\text { Non-governmental } \\
\text { Organization } \\
\text { Membership }\end{array}$} \\
\hline Yes & 18 & 9,00 & 17 & 9,20 & 35 & 9,10 \\
\hline No & 181 & 91,00 & 168 & 90,80 & 349 & 90,90 \\
\hline Total & 199 & 100,0 & 185 & 100,0 & 384 & 100,0 \\
\hline
\end{tabular}


According to the demographic characteristics of the sample, $50.5 \%$ (194) of the consumers participated to the research are female and $49.5 \%$ (190) of them are male. $26.6 \%$ (102) of the consumers are between the age of 34 and 41;24.7\% (95) of consumers are between 26 and 33, and 21.6\% (83) of the consumers are between 18 and 25 years old. The number of the married participants is 224 (58.3\%) whereas the number of the single participants is $160(41.7 \%)$. According to the findings, most of the participants have between 1001 and 1500 TL monthly income and have a bachelor's degree. Only 9.1\% (35) of the participants are members of non-governmental organizations.

\section{FINDINGS}

\subsection{Validity and Reliability of Scales}

Before analyzing the hypotheses, validity and reliability of scales are assessed. In order to determine the validity of scales, factor analysis is used and for determing the reliability of scales Croncbach's Alpha is used as shown in Table 2. 
Table 2. The Validity and Reliability of Scales

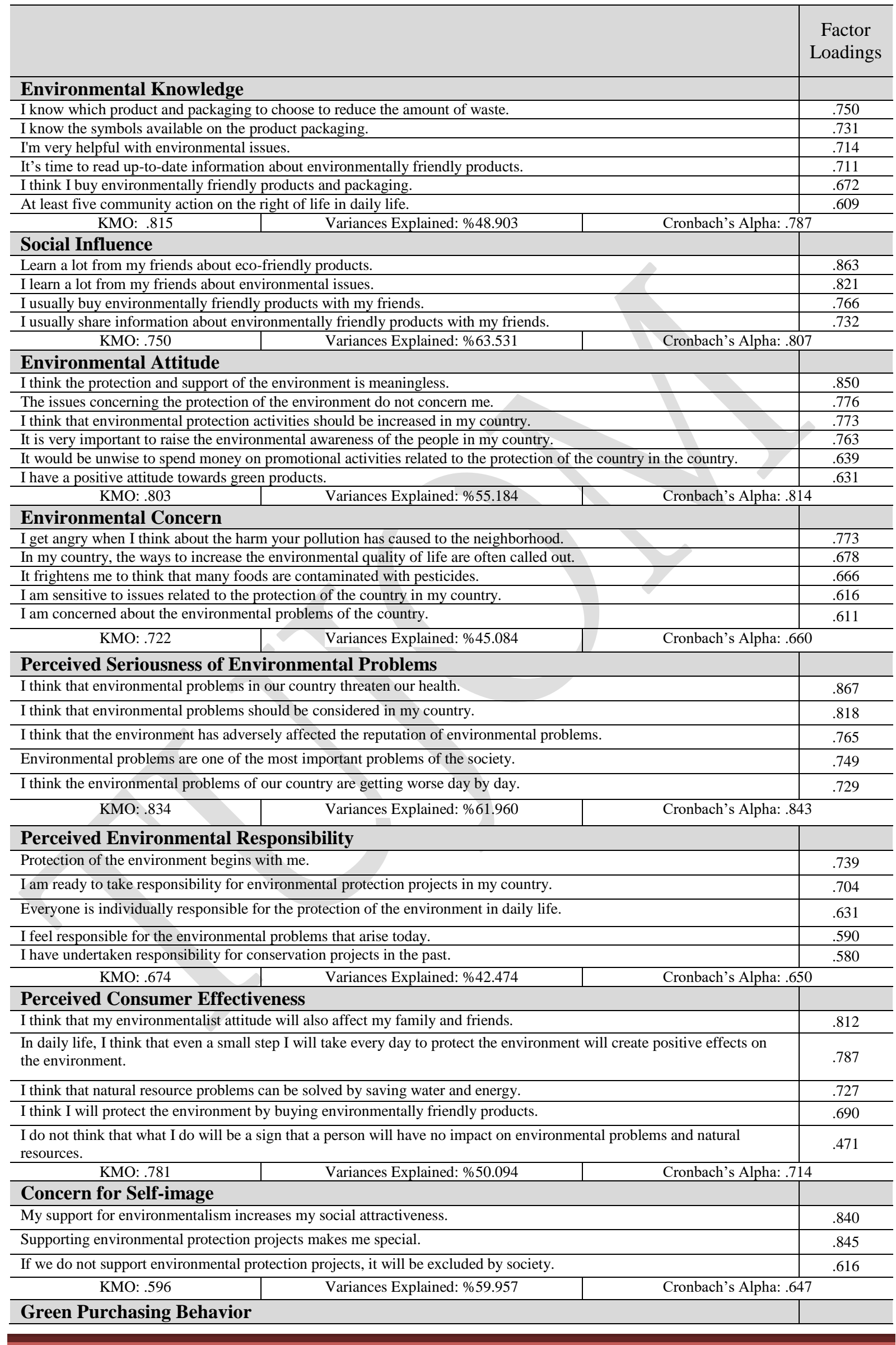




\begin{tabular}{|c|c|}
\hline Cleaning an environmental safety certificate or an organic certificate while purchasing a product. & .815 \\
\hline I make a special effort to buy recycled packaging products. & .809 \\
\hline I prefer eco-friendly products that do not harm the environment. & .750 \\
\hline I am willing to pay more for the purchase of eco-friendly products. & .718 \\
\hline When you buy a product, look at its contents to see if it contains harmful substances to the environment. & .722 \\
\hline If I have to choose between two products of the same quality, I choose the less harmful one around and collecting. & .509 \\
\hline
\end{tabular}

The reliability of scales is greater than 0.60 ; so that all of the scales used in this research are accepted as reliable (Özdamar, 1997) and all scales validity scores are higher than 0.40 which is acceptable level (Kalayc1, 2008).

\subsection{Hypotheses Testing}

In order to find out differences between the antecedents of green buying behavior and green purchasing behavior of Turkish and Persian consumers, $t$ test is conducted.

Table 3. Analyzing Differences between the Antecedents of Green Purchasing Behavior and Green Purchasing Behavior of Turkish and Persian Consumers

\begin{tabular}{|c|c|c|c|c|c|c|c|}
\hline & \multicolumn{2}{|c|}{$\begin{array}{l}\text { Levene's Var. } \\
\text { F Statistics }\end{array}$} & \multicolumn{5}{|c|}{ t-test } \\
\hline & $\mathrm{F}$ & Sig. & $\mathrm{T}$ & $\mathrm{df}$ & $\begin{array}{l}\text { Sig. (2- } \\
\text { tailed) }\end{array}$ & $\begin{array}{c}\text { Average } \\
\text { Difference }\end{array}$ & $\begin{array}{l}\text { Standard Error } \\
\text { Difference }\end{array}$ \\
\hline EK & ,878 & ,349 & $-3,102$ & 382 &, $002 *$ &,- 21493 & ,06928 \\
\hline SI & ,067 & ,796 & $-2,069$ & 382 & ,039* &,- 16471 & ,07961 \\
\hline EA & 1,620 & ,204 & $-1,114$ & 382 & ,266 &,- 08150 &, 07316 \\
\hline EC & ,318 & ,573 & 2,925 & 382 &, $004 *$ & , 17751 & ,06070 \\
\hline PSEP & 7,612 & ,006 & $-2,607$ & 368,101 &, $010 *$ &,- 18813 & ,07216 \\
\hline PER & 3,242 & ,073 &,- 947 & 382 & ,344 &,- 05866 & ,06191 \\
\hline PCE & ,203 & ,653 &,- 266 & 382 & ,791 &,- 01704 & ,06414 \\
\hline CSI &, 012 & ,912 & $-4,383$ & 382 &, $000 *$ &,- 35821 & ,08173 \\
\hline GPB & 1,643 & ,201 & $-2,239$ & 382 & ,026* &,- 15717 & ,07018 \\
\hline
\end{tabular}

EK=Environmental Knowledge SI=Social influence; EA=Environmental Attitudes; EC=Environmental concern; PSEP=Perceived

Seriousness of Environmental Problems; PER=Perceived Environmental Responsibility; PCE=Perceived Consumer Effectiveness; $\mathrm{CSI}=$ Concern for Self-Image; GPB=Green Purchasing Behavior

Based on the results of t-test, there is a significant difference between the antecedents of green purchasing behavior such as environmental knowledge, social influence, environmental concern, perceived seriousness of environmental problems and concern for self-image of Turkish and Persian consumers. In addition, green purchasing behavior of Turkish and Persian consumers also differs. Thus, $\mathrm{H}_{1 \mathrm{a}}, \mathrm{H}_{1 \mathrm{~b}}, \mathrm{H}_{1 \mathrm{~d}}, \mathrm{H}_{1 \mathrm{e}}, \mathrm{H}_{1 \mathrm{~h}}$, and $\mathrm{H}_{2}$ are supported whereas $\mathrm{H}_{1 \mathrm{c}}, \mathrm{H}_{1 \mathrm{f}}$ and $\mathrm{H}_{1 \mathrm{~g}}$ are not supported. 
Tablo 4. Comparisons Between Antecedents of Green Purchasing Behavior and Green Purchasing Behavior of Turkish and Persian Consumers

\begin{tabular}{c|c|c|c|c|c|c|c|c}
\hline & \multicolumn{4}{|c|}{ Turkish Consumers } & \multicolumn{4}{c}{ Persian Consumers } \\
\hline & $\mathrm{N}$ & Mean & df & SE & $\mathrm{N}$ & Mean & Df & SE \\
\hline EK & 199 & 3,3878 &, 69790 &, 04947 & 185 & $\mathbf{3 , 6 0 2 7}$ &, 65660 &, 04827 \\
\hline SI & 199 & 3,0515 &, 77617 &, 05502 & 185 & $\mathbf{3 , 2 1 6 2}$ &, 78315 &, 05758 \\
\hline EA & 199 & 4,1177 &, 73665 &, 05222 & 185 & 4,1992 &, 69382 &, 05101 \\
\hline EC & 199 & $\mathbf{3 , 9 7 5 7}$ &, 61714 &, 04375 & 185 & 3,7982 &, 56876 &, 04182 \\
\hline PSEP & 199 & 4,1146 &, 79857 &, 05661 & 185 & $\mathbf{4 , 3 0 2 7}$ &, 60867 &, 04475 \\
\hline PER & 199 & 3,6918 &, 58693 &, 04161 & 185 & 3,7505 &, 62630 &, 04605 \\
\hline PCE & 199 & 3,9538 &, 64281 &, 04557 & 185 & 3,9708 &, 61167 &, 04497 \\
\hline CSI & 199 & 2,9715 &, 79686 &, 05649 & 185 & $\mathbf{3 , 3 2 9 7}$ &, 80382 &, 05910 \\
\hline GPB & 199 & 3,5888 &, 71122 &, 05042 & 185 & $\mathbf{3 , 7 4 5 9}$ &, 66031 &, 04855 \\
\hline
\end{tabular}

EK=Environmental Knowledge SI=Social influence; EA=Environmental Attitudes; EC=Environmental concern; PSEP=Perceived Seriousness of Environmental Problems; PER=Perceived Environmental Responsibility; PCE=Perceived Consumer Effectiveness; CSI=Concern for Self-Image; GPB=Green Purchasing Behavior

According to the Table 4 for finding out differences between antecedents of green purchasing behavior and green purchasing behavior of Turkish and Persian consumers, $t$ test is conducted. To the results, the environmental knowledge of Persian consumers $(\mu=3.6027)$ is higher than Turkish consumers $(\mu=3.3878)$. Turkish consumers' social influence is $(\mu=3.0515)$ lower than the Persian consumers' $(\mu=3.2162)$. Social influence of Persian consumers is higher than Turkish consumers. Turkish consumers' environmental concern is ( $\mu=3.9757)$ higher than the Persian consumers' $(\mu=3.7982)$. Turkish consumers' perceptions about seriousness of environmental problems $(\mu=4.1146)$ are less than the Persian consumers' $(\mu=4.3027)$. Turkish consumers' concern for self-image $(\mu=2.9715)$ is less than Persian consumers' concern for self-image $(\mu=3.3297)$. The Persian consumers' green purchasing ( $\mu=3.7459)$ is greater than the Turkish consumers' green purchasing $(\mu=3.5888)$.

\section{CONCLUSION}

The concerns of consumers about future are in parallel with the increase of environmental problems and its reflections on the consumers' buying behavior have led the companies to apply environmentalist policies and strategies. In this context, identifying green purchasing behavior of consumers and finding their antecedents of green buying behavior has become an important issue for marketing.

In this study, environmental knowledge, social influence, environmental attitude, environmental concern, perceived seriousness of environmental problems, perceived environmental responsibility, perceived consumer effectiveness and concern for self-image are examined as antecedents of green purchasing behavior. 
This study is a detailed analysis on the differences between both antecedents of green purchasing behavior and green purchasing behavior of Turkish and Persian consumers. The two emerging countries in the Middle East are Turkey and Iran having historical and cultural ties, and neighbor relations are examined in the study. Both countries are close to each other in terms of their population, human resources and economic similarities. In addition, both Turkey and Iran have collectivistic culture. Iran and Turkey have strong cultural rules thus traditions are important for them (Hofstede Center 2017).

In collectivistic cultures, individuals highlight conformity for group harmony (Kim and Drolet, 2003) and refrain from expressing their distinctiveness (Xu et al., 2014). On the contrary, individualistic cultures put higher values on individual rather than group interests, expecting individuals to show themselves freely (Chan and Lau, 2002).

Even though Turkish and Persian community are known as collectivistic, Persian community is found to be more collectivistic than Turkish community which means that consumers care more about what others think than what they think themselves. The social pleasure in Iran can be the cause of this situation.

According to the results, significant differences are found between five antecedents of green purchasing behavior such as environmental knowledge, social influence, environmental concern, perceived seriousness of environmental problems and concern for self-image of Turkish and Persian consumers. In addition, green purchasing behavior of Turkish and Persian consumers also differs from each other.

Environmental knowledge, social influence, perceived seriousness of environmental problems, concern for self-image and green purchasing of Persian consumers are higher than Turkish consumers. Turkish consumers' environmental concern is higher than the Persian consumers'. Thus, differences are found between two consumer groups' green purchasing behavior. Based on the results, it can be concluded that Persian consumers' green purchasing behavior is more affected by the social pressure.

This study examined green purchasing behavior of consumers from different cultures in order to explore differences between them. As the consumers' cultures and lifestyles differs, their buying behavior also varies. Consumers with dissimilar cultures could be different in terms of green purchasing behavior (Chan and lau 2002). 
Marketers try to understand the consumer behavior and their antecedents in order to set strategies. Thus, this study's findings can make both contributions to the literature of green marketing and it can also help practitioners in their strategic decisions especially for importing and exporting in global area.

\section{THEORETICAL AND MANAGERIAL CONTRIBUTIONS}

This study has investigated the Turkish and Persian consumers' antecedents of green purchasing behavior and green purchasing behavior comparatively. Thus, it is hoped that it will have important theoretical contributions to the literature for analyzing of green purchasing behavior of consumers in emerging markets in detailed scope.

Nowadays environmental issues are important for marketers in the field. The results of this research provide important issues for companies. The companies can gain competitive advantage by taking these hints into consideration. For this reason, studying the antecedents of consumer's green purchasing behavior will be helpful for the international marketers especially operating in emerging markets such as Turkish and Persian consumers. All marketing strategies can also be shaped according to the preferences of consumers in the green marketing.

\section{LIMITATIONS AND SUGGESTIONS FOR FUTURE RESEARCH}

As a suggestion for future studies apart from the antecedents of green purchasing behavior examined in this study, other factors affecting the green purchasing behavior can be included. In order to see the changes in consumers' green purchasing behavior of Turkish and Persian consumers, this study can also be repeated in the future. For future studies, it would be beneficial to analyze the different consumer groups' green purchasing behavior in different emerging markets. In addition, different methods such as observation can be used in order to assess the green purchasing behavior of consumers in the future studies. 


\section{REFERENCES}

Afsordegan, F., Hamdi, K., \& Ghaffari, F. (2011). Study on the effective factors on young consumer's green willingness: Tehran case study. Journal of Marketing Management. V(6).

Akehurst, G., Afonso, C., \& Gonçalves, H.M. (2012). Re-examining green purchase behavior and the green consumer profile: new evidence, Management Decision. 50(5), 972-988.

Bagheri, S. J. (2014). Green marketing and its impacts on consumer behavior in sports shops. Annals of Applied Sport Science, 2(2), 75-82. Retrieved from:http://aassjournal.com/article-1-189-en.pdf

Baker, J. P., \& Ozaki, R. (2008). Pro-environmental products: Marketing influence on consumer purchase decision. Journal of Consumer Marketing, 25(5), 281-293.

Çetinkaya, C., \& Özceylan E., (2017). A survey on university students' attitudes on green products: A case study in Gaziantep University. Gaziantep University Journal of Social Sciences, 16(1), 289-302.

Chan, R.Y.K., \& Lau, L. B.Y. (2002). Explaining green purchasing behavior: a cross-cultural study on American and Chinese consumers. Journal of International Consumer Marketing, 14, 9-40. https://doi.org/10.1300/J046v14n02_02

Chan, R.Y.K., \& Lau, L. B.Y. (2000). Antecedents of green purchases: a survey in China. Journal of Consumer Marketing, 17(4), 338-357.

Chan, R.Y.K., \& Yam, E. (1995). Green movement in a newly industrializing area: a survey on the attitudes and behavior of the Hong Kong citizens. Journal of Community and Applied Social Psychology, 5(2), $73-84$.

Cheah, C.M., 2009. A study on consumers green purchasing intention. Master's Thesis of Business, University Utara Malaysia, Malaysia.

D’Souza C., Taghian M., \& Lamb P. (2006). An empirical study on the influence of environmental labels on consumers. Corporate Communication: An International Journal, 11(2), 162-173.

Erten, S. (2004). Çevre eğitimi ve çevre bilinci nedir, çevre eğitimi nasıl olmalıdır? Çevre ve İnsan Dergisi, Çevre ve Orman Bakanlı̆̆ı Yayın Organı, from:http://yunus.hacettepe.edu.tr/ serten/makaleler/cevre.pdf

Follows, S. B., \& Jobber, D. (2000). Environmentally responsible purchase behavior: a test of a consumer model. European Journal of Marketing, 34(5/6), 723-746.

Fraj, E., \& Martinez, E. (2006). Environmental values and lifestyles as determining factors of ecological consumer behavior: an empirical analysis. The Journal of Consumer Marketing, 23(3), 133-144. 
Garcia-Mira, R., Real, J.E., \& Jose, R. (2005). Temporal and spatial dimensions in the perception of environmental problems: an investigation of the concept of environmental hyperopia. International Journal of Psychology, 40(1), 5-10.

Geller, E.S. (1981). Evaluating energy conservation programs: is verbal report enough? Journal of Consumer Research, 8(3), 331-335.

Gezer, K., Çokadar, H., Köse, S., \& Bilen, K. (2006). Lise öğrencilerinin çevreye yönelik tutumlarının karşılaştırılması. Buldan Sempozyumu, 23-24 Kasım: 71-78, Pamukkale Üniversitesi, Denizli. from:http://buldansempozyumu.pau.edu.tr/kitap/2.oturum/3.pdf

Ghimire, D.J., \& Mohai, P. (2005). Environmentalism and contraceptive use: how people in less developed settings approach environmental issues. Population and Environment, 27(1), 29-61.

Gilg, A., Barr, S., \& Ford, N. (2005). Green consumption or sustainable lifestyles? İdentifying the sustainable consumer. Futures, 37: 481-504.

Gurcemal, D. (2016) Uluslararası ekonomik politiği açısından Türkiye-İran İlişkileri Yayınlanmamış Yüksek Lisans Tezi, Yeniyüzyıl Üniversitesi Sosyal Bilimler Enstitüsü, İstanbul, PP(17).

Hartmann, P., \& Apaolaza-Ibanez, V. (2012). Consumer attitude and purchase intention toward green energy brands: the roles of psychological benefits and environmental concern. Journal of Business Research, 65, 12541263.

Hazır, A. (2015). Comparing Turkey and Iran in political science and historical sociology: A critical review. Turkish Journal of Middle Eastern Studies, 2(1), 1-30.

Hofstede Center (2017). Scores for individualism for Turkey and Iran. Retrieved from http://geerthofstede.com/turkey/iran.html

Hoyer, W. D. \& Mac Innis, D. (2004). Consumer behavior, Houghton Miffin, Boston: MA.F.

Hüseyin, A. T., \& Cankül, D. (2010). A research aiming to assign behaviors of university students: 'green marketing activities'. Ticaret ve Turizm Eğitim Fakültesi Dergisi, 1, 51-67. from:http://www.acarindex.com/dosyalar/makale/acarindex-1423913670.pdf

Kaiser, F.G., Wölfing, S., \& Fuhrer, U. (1999). Environmental attitude and ecological behavior. Journal of Environmental Psychology, 19, 1-19. from:https://home.zhaw.ch/cahu/dateien/Kaiser-Woelfing-Fuhrer99.pdf

Kalaycı, Ş. (2008). SPSS uygulamalı çok değişkenli istatistik teknikleri. 3. Baskı. Asil Yayın Dağıtım A.Ş. Ankara.

Kement, U. (2018). Çevresel kaygı ve algılanan ahlaki yükümlülüğün yeşil otelleri ziyaret etme niyetine etkisinin incelenmesi, Turizm Akademik Dergisi, 5 (2), 203-214. 
Khare, V., Garg, S., Shukla, S., \& Sharma, P. (2013). Comparative study of 1G, 2G, 3G and 4G. Journal of Engineering Computers and Applied Sciences, 2(4), 55-63.

Kim, H. S., \& Drolet, A. (2003). Choice and self-expression: a cultural analysis of variety-seeking. Journal of Personality and Social Psychology, 85(2), 373-382. https://doi.org/10.1037/0022-3514.85.2.373

Kim, C., \& Fortner, R.W. (2006). Issue-specific barriers to addressing environmental issues in the classroom: an explanatory study. The Journal of Environmental Education, 37(3), 15-22.

Kim, Y. (2011). Understanding green purchase: the influence of collectivism, personal values and environmental attitudes, and the moderating effect of perceived consumer effectiveness. Seoul Journal of Business, 17(1), 6592.

Kim, Y., \& Choi, S.M. (2005). Antecedents of green purchase behavior: an examination of collectivism, environmental concern, and PCE. Advances in Consumer Research, 32, 592-599.

Kinnear, T., Taylor, J., \& Ahmed, S. (1974). Ecologically concerned consumers: who are they. Journal of Marketing, 38 (April). 20-24.

Kotchen, J. M., \& Reiling, S. D. (2000) Environmental attitudes, motivations, and contingent valuation of nonuse values: a case study involving endangered species. Ecological Economics, 32(1), 93-107. https://doi.org/10.1016/S0921-8009(99)00069-5

Lai, O. K. (2000). Greening of Hong Kong? forms of manifestation of environmental movements. In S. W. $\mathrm{K}$.

Chiu \& T. L. Lui (Eds.), The dynamics of social movements in Hong Kong, 259-296. Hong Kong: Hong Kong University Press.

Lascu, D.N., \& Zinkhan, G. (1999). Consumer conformity: review and applications for marketing theory and practice. Journal of Marketing Theory and Practice, 8, 1-12.

Lee, K. (2008). Opportunities for green marketing: young consumers. Marketing Intelligence and Planning, 26(6), 573-586.

Lee, K. (2009). Gender differences in Hong Kong adolescent consumers' green purchasing behavior. Journal of Consumer Marketing, 26(2) 87-96.

Lee, K. (2011). The green purchase behavior of Hong Kong young consumers: the role of peer influence, local environmental involvement, and concrete environmental knowledge. Journal of International Consumer Marketing, 23, 21-44.

Lee, Y. L., Haley, E., \& Yang, K. (2017). The role of organizational perception, perceived consumer effectiveness and self-efficacy in recycling advocacy advertising effectiveness, Environmental Communication, $1-16$. 
Leonidou, L.C., Katsikeas, C.S., \& Coudounaris, D. (2010). Five decades of business research into exporting a bibliography analysis, Journal of International Management, 16(1), 78-91.

Majlath, M. (2010). Can individuals do anything for the environment? the role of perceived consumer effectiveness. FIKUSZ '10 Symposium for Young Researchers, 157-166, Budapest, Hungary.

Maloney, M. P., \& Ward, M. P. (1973). Ecology: let's hear from the people: an objective scale for the measurement of ecological attitudes and knowledge. American Psychologist, 28(7), 583-586. from:http://dx.doi.org/10.1037/h0034936

Manzo, L.C., \& Weinstein, M.D. (1987). Behavioral commitment to environmental protection: A study of active and nonactive members of the Sierra Club. Environment and Behavior, 19, 673-694.

Mei, O. J., Ling, K. C., \& Piew, T, H. (2012). The antecedents of green purchase intention among Malaysian $\begin{array}{lllll}\text { consumers. } & \text { Asian } & \text { Social } & \text { Science, } & 8(13),\end{array}$ http://citeseerx.ist.psu.edu/viewdoc/download?doi=10.1.1.920.3195\&rep=rep1\&type=pdf

Mohd Suki, N. (2013). Young consumer ecological behavior: the effects of environmental knowledge, healthy food, and healthy way of life with the moderation of gender and age. Management of Environmental Quality: An International Journal, 24(6), 726-737.

Moser, G., \& Uzzell, D. (2003). Environmental psychology. In Weiner, I., Millon, T. \& Lerner, M. (Eds.), Handbook of Psychology, Personality and Social Psychology, 419-446.

Mostafa, M.M. (2006). Antecedents of Egyptian consumers' green purchase intentions: a hierarchical multivariate regression mode. Journal of International Consumer Marketing, 19(2), 97-124.

Mostafa, M.M. (2007). A hierarchical analysis of the green consciousness of the Egyptian consumer. Psychology and Marketing, 24(5), 445-473.

Mostafa, M.M. (2009). Shades of green: A psychographic segmentation of the green consumer in Kuwait using self-organizing maps. Expert Systems with Applications, 36(8), 11030-11038.

Muller, T.E., \& Taylor, D.W. (1991). Eco-literacy among consumers-how much do they know about saving their planet? In: H. Burkhardt and W. E. Vandenburg (Eds.), Preparing for Sustainable Society, 413-420. Ryerson Polytechnical Institue, Toronto.

Oliver, H., Volschenk, J., \& Smit, E. (2011). Residential consumers in the Cape Peninsula's willingness to pay for premium priced green electricity. Energy Policy, 39: 544-550.

Onurlubaş, E. (2019). The effects of social impact, environmental awareness and environmental consciousness on green product purchasing behaviour. Turkish Journal of Agriculture - Food Science and Technology, 7(3): 447-457, DOI: https://doi.org/10.24925/turjaf.v7i3.447-457.2403

Özbay, Ş. (2010). Fen ve teknoloji programı içinde kompost hakkında verilen etkinliklerin öğrencilerin akademik başarılarına ve çevre tutumlarına etkisi”, Yüksek Lisans Tezi, Fen Bilimleri Enstitüsü, Çanakkale. 
Özdamar, K. (1997), Paket Programlar ile İstatistiksel Veri Analizi, T.C. Anadolu Üniversitesi Yayınları, Eskişehir.

Özdemir, A. (2003). İlköğretim sekizinci sınıf öğrencilerinin çevre bilgi ve bilinçlerinin araştırılması. Yayımlanmamış Doktora Tezi, Dokuz Eylül Üniversitesi, Eğitim Bilimleri Enstitüsü, İzmir.

Panni, M.F.A.K. (2006). The effect of consumerism towards customer attitudinal behavior in food industry in Malaysia. M.Phil. Multimedia University.

Prakash, A. (2002). Green marketing, public policy and managerial strategies. Business Strategy and the Environment, 11: 19-25.

Renner, M. (2002). The power of green consumers: Review of Vital Signs.

Roberts, J.A. (1996). Green consumers in the 1990s: profile and implications for advertising. Journal of Business Research, 36(3), 217-231.

Samdahl, D.M., \& Robertson, R. (1989). Social determinants of environmental concern: specification and test of the model. Environment and Behavior, 21(1), 57-81.

Saritas, A. (2018). The role of interest in environmental effects of consumer activities determined by green purchasing behavior. Journal of Social Research and Behavioral Sciences, 4(5), 47-71.

Schultz, P. W., \& Zelezny, L. (1999). Values as predictors of environmental attitudes: evidence for consistency across 14 countries. Journal of Environmental Psychology, 19, 255-265.

Sharma, B. (2014). Consumers' attitudes, green practices, demographic and social influences, and government policies: an empirical investigation of their relationships. Journal of New Business Ideas \& Trends, 12(2), 22 36.

Silver, C. (2019). IMF's world economic outlook database. https://www.investopedia.com/insights/worlds-topeconomies/

Sinnappan, P., \& Rahman, A.A. (2011). Antecedents of green purchasing behavior among Malaysian consumers. International Business Management, 5(3), 129-139.

Soonthonsmai, V. (2007). Environmental or green marketing as global competitive edge; concept, synthesis, and implication, EABR (Business) and ETLC (Teaching), Conference Proceeding, Venice, Italy.

Straughan, R. D., \& Roberts, J. A. (1999). Environmental segmentation alternatives: a look at green consumer behavior in the new millennium. Journal of Consumer Marketing, 16 (6), 558-575. 
Tanrikulu, C. (2015). An examination of the role of environmental concern, perceived consumer effectiveness, and collectivism in green purchase behavior of consumers. Atatürk Üniversitesi İktisadi ve İdari Bilimler Dergisi, 29(1), 121-136. from:http://dergipark.gov.tr/download/article-file/30594

Tilikidou, I. (2007). The effects of knowledge and attitudes upon Greeks' pro-environmental purchasing behavior. Corporate Social Responsibility and Environmental Management, 14(3), 121-134.

Uddin, S.F., \& Khan, M.N. (2016). Exploring green purchasing behavior of young urban consumers: Empirical evidences from India. South Asian Journal of Global Business Research, 5(1), 85-103.

Ünlüönen, K. \& Tayfun, A. (2003). A ampric research over the impacts of tourists on the consume habits of residents. Muğla Üniversitesi Sosyal Bilimler Enstitüsü Dergisi, 10(2), 133-150.

Xu, A. J., Loi, R., \& Ngo, H. Y. (2014). Ethical leadership behavior and employee justice perceptions: the mediating role of trust in organization. Journal of Business Ethics, 493-504. https://doi.org/10.1007/s10551-0142457-4.

Yahya, W. K., Hashim, N. H, Mohamad, S. A., \& Ramly, Z. (2013). The relationship between perceived consumer effectiveness, environmental concern and ecologically conscious consumer behavior. 3rd Annual International Conference on Business Strategy and Organizational Behaviour, 93-98.

Y1lmaz, V., \& Arslan, T. (2011). Examining the university students' environmental protection commitments and environment-friendly consumption behaviors. Anadolu Üniversitesi Sosyal Bilimler Dergisi, 11(3), 1-10. from:http://sbd.dergi.anadolu.edu.tr/makale_goster.php?id=1010

Zainudin, A., Saripah, A.L., Mohd Shukri, O., \& Yeop Hussin, B. (2013). From research to practice: role of environmental knowledge in creating pro-environmental residents. Procedia-Social and Behavioral Sciences 105 , 866-874. from:https://core.ac.uk/download/pdf/82277087.pdf

Zinkhan, G.M., \& Les C. (1995). Green advertising and the reluctant consumer. Journal of Advertising, 24(2), 16.

Wikipedia: The free encyclopedia. Inc. Retrieved $15 \quad$ February 2020. https://en.wikipedia.org/wiki/Iran\%E2\%80\%93Turkey_relations 